І. В. Козлова, С. В. Федоров

ДВНЗ “Івано-Франківський національний медичний університет”

\title{
МОЖЛИВОСТІ ДИСТАНЦІЙНОЇ ФОРМИ ОСВІТИ У ПІСЛЯДИПЛОМНІЙ ПІДГОТОВЦІ ЛІКАРІВ ЗАГАЛЬНОЇ ПРАКТИКИ - СІМЕЙНОЇ МЕДИЦИНИ
}

\author{
I. V. Kozlova, S. V. Fedorov \\ SHEI “Ivano-Frankivsk National Medical University” \\ THE POSSIBILITIES OF DISTANCE FORM OF EDUCATION IN \\ POSTGRADUATE TRAINING FOR FAMILY MEDICINE SPECIALISTS
}

\begin{abstract}
Мета роботи - окреслити проблеми впровадження дистанційної форми навчання у процес післядипломного удосконалення лікарів.

Основна частина. У статті наведені основні проблеми впровадження дистанційної форми навчання для слухачів циклів післядипломного удосконалення за спеціальністю “Загальна практика - сімейна медицина”. Розглянуті технології дистанційного навчання, необхідні зміни організаційних принципів навчання та заходи, спрямовані на вдосконалення навчального процесу.

Висновки. Впровадження дистанційного навчання вимагає вдосконалення та адаптації як до умов функціонування первинної ланки охорони здоров'я, так і до суб'єктивного сприйняття лікарями-спеціалістами. Основою дистанційного навчання на післядипломному етапі освіти лікаря є самостійна робота з використанням інформаційних технологій.
\end{abstract}

Ключові слова: дистанційна освіта; технології; загальна практика - сімейна медицина.

The aim of the study - to describe of the problem of distance learning implementation to the process of postgraduate doctors improvement.

The main body. The basic problems of distance learning implementation for students of postgraduate cycles on "General practicefamily medicine” specialty are described in the article. Distance learning technics, necessary changes of organizational training principles and measures for educational process improvement are considered.

Conclusion. The implementation of distance learning requires improvement and gear to conditions of primary health care functioning as well as for subjective perception of medical specialists. The basis of the distance learning on the postgraduate medical education stage is individual work with information technology usage.

Key words: distance education; technic; general practice - family medicine.

Вступ. Світова медична практика на сучасному етапі показує, що потреба в наданні первинної допомоги населенню у багато разів перевищує потреби суспільства у наданні спеціалізованої та високотехнологічної допомоги. У більшості країн світу заклади первинної ланки надають до 90 \% загального обсягу медичної допомоги [1]. Світовий досвід, підсумований ВООЗ, свідчить, що розвиток первинної допомоги на засадах сімейної медицини $€$ найефективнішим засобом досягнення справедливого розподілу і раціонального використання коштів та підвищення результативності роботи усієї галузі охорони здоров’я [1, 2].

(ㄷ І. В. Козлова, С. В. Федоров
Проблема післядипломної підготовки лікарів загальної практики з'явилася одночасно з уведенням цієї спеціальності й обумовлена тим, що вперше у вітчизняній системі охорони здоров'я виникла потреба в професійній перепідготовці великої кількості лікарів, які працюють в умовах первинної ланки надання медичної допомоги. Саме тому одним із важливих напрямків післядипломної підготовки спеціалістів $є$ створення системи безперервної медичної освіти, яка дозволяє лікарямспеціалістам постійно підтримувати необхідний рівень професійної компетентності. У зв'язку 3 цим, розробка принципів дистанційного навчання та впровадження їх у практику навчання лікарів за 
спеціальністю “Загальна практика - сімейна медицина” вбачається особливо актуальною $[1,3]$.

Мета роботи - окреслити проблемні питання, що впливають на ефективність впровадження дистанційної форми навчання у процес післядипломного удосконалення лікарів за спеціальністю “Загальна практика - сімейна медицина”.

Для реалізації поставленої мети нами проведено вивчення, аналіз та узагальнення сучасних літературних наукових даних, які у світлі проблем реформування медичної галузі відображають проблемні питання впровадження дистанційної форми навчання у процес післядипломної освіти лікарів, у тому числі за спеціальністю “Загальна практика - сімейна медицина”.

Основна частина. У наш час дистанційне навчання набуває все більшої поширеності. Розвиток дистанційної форми навчання обумовлений швидкою зміною медичних технологій, що вимагає практично безперервного навчання лікарів, та широким впровадженням інформативно-комунікаційних технологій і технологій мобільності, які дозволяють його здійснювати. Дистанційне навчання дає можливість ефективного безперервного навчання протягом усього життя, навчання “без меж” та в інтерактивному режимі. Проте, чи є ефективним дистанційне навчання в медицині та чи є можливим забезпечення клінічних навиків при дистанційній формі навчання без інтегрованого підходу “обличчя до обличчя”? Без сумніву, засвоєння практичних навичок вимагає традиційного очного контакту з викладачем і пацієнтом, однак теоретична підготовка може відбуватись у дистанційній формі. Дистанційна освіта не замінюється синонімом заочна. Вона відрізняється від останньої зручною системою доставки інформації, пропонує широкий тематичний діапазон курсів удосконалення та дозволяє скоротити час навчання завдяки швидкості комунікації [2].

Сьогодні дистанційне навчання розглядається як форма організації і реалізації навчально-виховного процесу, за якою його учасники здійснюють навчальну взаємодію переважно екстериторіально (тобто на відстані, коли слухач і викладач фізично відокремлені відстанню, яка не дозволяє і не передбачає безпосередню навчальну взаємодію учасників віч-на-віч, інакше кажучи, коли учасники територіально знаходяться поза межами можливої безпосередньої навчальної взаємодії і коли у процесі навчання їх особиста присутність у певних навчальних приміщеннях навчального закладу не $є$ обов'язковою, а систематичне відвідування занять не передбачається) [3].

Особливо активно процес впровадження дистанційного навчання торкається післядипломної освіти лікарів. Прагнення лікаря-спеціаліста до постійного удосконалення вимагає від освітніх закладів оптимізації навчального процесу з урахуванням вітчизняних та зарубіжних принципів надання медичної допомоги [2, 3].

Перевагами дистанційної форми навчання на сьогодні вважають доступність для всіх, гарантовану якість навчання, можливість навчання за місцем проживання, що сприяє розширенню кола слухачів (особливо із віддалених районів), економію часових та фінансових затрат (у тому числі серед лікарів повної зайнятості з обмеженим часом для навчання), використання сучасних інформаційних систем (соціальних мереж, електронних бібліотек, on-line конференцій, майстер-класів, оцінювання отриманих знань у системі on-line); безпосередній контакт із вітчизняними і зарубіжними фахівцями (телемедицина, відеоконференція), архівування отриманих знань [2, 4]. Відхід від класичного викладання “з трибуни” і впровадження інтерактивних методів навчання, що активно залучають слухачів до процесу здобуття знань, можуть сприяти формуванню потреби в самостійній роботі за рамками часу, відведеного на очну частину навчання [4].

Разом із тим, існує ряд труднощів, які необхідно враховувати при впровадженні дистанційної форми навчання. Важливим є кваліфікований підхід до розробки та впровадження навчальних програм, які гарантуватимуть високу якість освіти, і забезпечення контролю отриманого клінічного досвіду. Варто враховувати і ставлення до даного виду навчання викладача, який повинен не тільки підготувати великий обсяг навчальних матеріалів, але й бути постійною контактною особою для визначеної групи слухачів упродовж певного періоду часу $[1,5]$. На сьогодні не впроваджені нормативні документи, що стосуються розрахунку навантаження педагогічної діяльності в режимі on-line, не вирішені питання розрахунку методичної роботи, котра якісно відрізняється від попередньої діяльності. Окрім того, не налагоджена система підготовки викладачів стосовно методик дистанційної форми навчання. Такий підхід зумовлює використання термінології без розуміння суті процесу [5].

До того ж, не всі слухачі циклів післядипломного удосконалення позитивно сприймають дистанційну 
форму навчання, мотивуючи свою позицію наступними моментами $[2,6]$ :

- дистанційне навчання сприймається як складніше з ряду причин - від недостатнього володіння комп’ютерною технікою до небажання працювати самостійно. Очне навчання, котре грунтується на лекціях і, зазвичай, завершується заліком або іспитом із мінімальною ймовірністю невдачі, не висуває великих вимог до тих, хто навчається. На противагу цьому, дистанційне навчання вимагає самоосвіти, і звичної присутності на заняттях недостатньо;

- слухачі мають недовіру до електронних засобів комунікації. Останнє пов’язане з припущенням про те, що в Інтернеті можуть публікуватись недостовірні (науково необгрунтовані дані), а навчальні установи перебувають під суворим контролем і пропонують найбільш якісну освіту;

- у слухачів існує страх перед технічними засобами навчання. Далеко не всі слухачі уміють користуватися комп’ютерами та Інтернетом.

Для того щоб дистанційна форма навчання була якісною та успішною, необхідна відповідна нормативно-правова база, інформаційне забезпечення у вигляді баз даних слухачів, викладачів, навчальних матеріалів, які дозволяють швидко та ефективно організувати заняття і проводити необхідний різноплановий облік. 3 цією метою використовують певні технології дистанційного навчання, які передбачають [1, 2, 7]:

- подання завдань і навчальних посібників, а також повернення виконаних завдань у вигляді мультимедійної інформації поштою, факсом, електронною поштою;

- комп’ютерне навчання з використанням мережі “Інтернет”, включаючи локальні мережі (навчальні програми, електронні підручники, комп’ютерні тести, матеріали електронних бібліотек, мережеві бази даних); технологія доповнюється навчальними аудіо- та відеоматеріалами; у рамках даної технології використовується відеотрансляція, коли слухачі бачать і чують лектора, проте останній бачити та чути їх не може; зворотний зв’язок із лектором може бути налагоджений за допомогою електронної пошти чи мобільного зв'язку;

- електронна конференція (форум у мережі “Інтернет”) у режимі offline як складова частина чи самостійний навчальний процес, коли кожен учасник залишає своє повідомлення або коментар, котрий доступний для ознайомлення й обговорення усім учасникам форуму; такого типу конференції передбачають наявність сайта, на якому розміщуються надіслані матеріали; за допомогою електронних конференцій демонструють і обговорюють готові матеріали, координують навчальну та дослідницьку діяльність, отримують консультації;

- відеоконференція в режимі online дозволяє не відриваючись від місця роботи чи проживання та використовуючи переваги “живого” спілкування отримувати необхідні знання і навички; для передачі відеопотоку можуть використовуватись аналогові та цифрові канали передачі даних, у тому числі - супутникові;

- “багатоточкова” відеоконференція дозволяє спілкуватись у режимі реального часу одночасно багатьом учасникам; використання такої технології ефективне при зустрічних потоках інформації, коли в процесі навчання необхідний обмін думками та обговорення питань в оперативному режимі.

Методологічна база системи дистанційної освіти повинна включати: концептуальні моделі і дидактичні аспекти дистанційного навчання в системі охорони здоров'я; інтерактивні електронні навчальні посібники різного виду та призначення (навчальні програми, електронні підручники, комп’ютерні тести, бази знань тощо), доступні для слухачів за допомогою глобальної мережі “Інтернет” або локальних мереж (інтранет); систему підготовки викладачів-консультантів і способи їх взаємодії зі слухачами; методику тестування в системі дистанційного навчання та аналізу ефективності дистанційної оцінки знань у порівнянні з очною формою; способи передачі освітньої інформації; методи захисту інтелектуальної власності; систему ліцензування; економічні рішення реалізації дистанційної форми освіти [8].

Технологічна база системи дистанційного навчання лікарів повинна характеризуватись відкритими стандартами освітніх заходів дистанційного навчання, інтеграцією таких стандартів із популярними програмними платформами дистанційної освіти; моделлю і технологічним проектом системи; проектом інтеграції обладнання і програмного забезпечення [2, 3, 8].

Світовий досвід показує, що ефективність впровадження дистанційної форми навчання в галузі охорони здоров’я залежить від ряду факторів [5, 6]:

- забезпечення єдиного високого стандарту якості освітніх програм і процесу навчання завдяки залученню до його організації ведучих спеціалістів конкретного напрямку;

- залучення широкого кола слухачів; 
- точності планування навчального процесу;

- забезпечення безперервності процесу навчання, зворотного зв’ язку зі слухачами;

- забезпечення необхідним навчальним матеріалом;

- організації навчання і практичної діяльності як єдиного процесу;

- використання проміжних варіантів навчальних курсів;

- тестування слухачів на будь-якій стадії навчального процесу;

- врахування різноманітності контекстів навчання, сучасних соціально-економічних умов життя, що обмежують часті поїздки для отримання знань у стаціонарні освітні заклади, та характерного для системи охорони здоров’я обмеженого фінансування.

Використання дистанційних технологій у післядипломному вдосконаленні лікарів за спеціальністю “Загальна практика - сімейна медицина” дозволяє індивідуалізувати процес навчання для конкретного слухача, ефективно здійснювати контроль над процесом навчання та забезпечує постійний зворотний зв’ язок із викладачем. Окрім того, дистанційна форма навчання скорочує фінансові навантаження на систему охорони здоров'я,

\section{Список літератури}

1. Семкович Я. В. Дистанційне навчання як інноваційна форма організації післядипломної освіти лікарів / Я. В. Семкович // Науковий вісник Міжнародного гуманітарного університету. - 2014. - № 7. - С. 49-50.

2. Рыбакова Н. Н. Организация дистанционного обучения специалистов в последипломном образовании / Н. Н. Рыбакова, А. Ю. Цуканов // Омский научный вестник. - 2014. - Вып. № 2 (126). - С. 90-95.

3. Ляхоцька Л. Електронне навчання лікарів / Л. Ляхоцька, М. Ляхоцька // Теорія та методика управління освітою. - 2012. - № 8. - С. 1-18.

4. Єщенко А. В. Використання дистанційного навчання в системі післядипломної освіти: сучасне і майбутнє / А. В. Єщенко // Проблеми безперервної медичної освіти та науки. - 2013. - № 2 (10). - С. 5-10.

\section{References}

1. Semkovych, Ya.V. (2014). Dystantsiine navchannia yak innovatsiina forma orhanizatsii pisliadyplomnoi osvity likariv [Distance learning as an innovative form of postgraduate education organization]. Naukovyi visnyk mizhnarodnoho humanitarnoho universytetu - Bulletin обумовлену необхідністю безперервного навчання лікарів-спеціалістів, і створює передумови для покращення якості освітніх послуг [5-7].

Висновки. Зважаючи на реформування системи охорони здоров’я в Україні, підвищення якості післядипломної освіти лікарів загальної практикисімейної медицини, процес впровадження дистанційної форми навчання вимагає удосконалення та адаптації не тільки до умов функціонування первинної ланки надання медичної допомоги, але і до суб’ єктивного сприйняття лікарями-спеціалістами. Саме тому важливою основою дистанційного навчання на післядипломному етапі освіти лікаря загальної практики - сімейної медицини є самостійна цілеспрямована робота $з$ використанням сучасних інформаційних технологій, ефективність якої залежить від методологічно грамотної побудови навчального процесу та інформаційнокомунікаційних можливостей вищого навчального закладу.

Надалі планується проведення ретельного аналізу та оцінки нормативно-правових, економічних та матеріально-технічних можливостей і перспектив впровадження дистанційної форми навчання у процес післядипломного удосконалення лікарів.

5. Скрипник Л. М. До питання впровадження дистанційної освіти в процес навчання лікарів загальної практики - сімейної медицини / Л. М. Скрипник // Галицький лікарський вісник. - 2013. - Т. 2, № 1. - С. 112-115.

6. Симчич Х. С. Перспективи та проблеми безперервної освіти в сімейній медицині / Х. С. Симчич // Буковинський медичний вісник. - 2016. - Т. 20, № 4 (80). С. 246-249.

7. Юзбашева Г. С. Дистанційне навчання у післядипломній освіті як науковий суспільний пріоритет / Г. С. Юзбашева // Педагогічний альманах. - 2011. Вип. 11. - С. 220-226.

8. Скрипник Л. М. Дистанційна медична освіта: сучасні реалії та проблеми / Л. М. Скрипник // Архів клінічної медицини. - 2012. - № 2 (18). - С. 116-118.

of International Humanitarian University, 7, 49-50 [in Ukrainian].

2. Rybakova, N.N., \& Tsukanov, A.Yu. (2014). Organizatsyya distantsyonnogo obucheniya spetsialistov $\mathrm{v}$ poslediplomnom obrazovanii [Organization of distance 
training of specialists in postgraduate education]. Omskii nauchnyi vestnik - Omsk Scientific Bulletin, 2 (126), 90-95 [in Russian].

3. Liakhotska, L., \& Liakhotska, M. (2012). Elektronne navchannia likariv [Electronic doctors training]. Teoriia ta metodyka upravlinnia osvitoiu - The Theory and Methods of Education Management, 8, 1-18 [in Ukrainian].

4. Yeshchenko, A.V. (2013). Vykorystannia dystantsiinoho navchannia v systemi pisliadyplomnoi osvity: suchasne i maibutnie [The use of distance learning in postgraduate education: the present and the future]. Problemy bezperervnoi medychnoi osvity ta nauky - Problems of Uninterrupted Medical Training and Science, 2 (10), 5-10 [in Ukrainian].

5. Skrypnyk, L.M. (2013). Do pytannia vprovadzhennia dystantsiinoi osvity v protses navchannia likariv zahalnoi praktyky - simeinoi medytsyny [On the implementation of distance education in learning process of family doctors]
Halytskyi likarskyi visnyk - Galician Medical Journal, 2(1), 112-115 [in Ukrainian].

6. Symchych, Kh.S. (2016). Perspektyvy ta problemy bezperervnoi osvity v simeinii medytsyni [Prospects and challenges of continuing education in family medicine]. Bukovynskyi medychnyi visnyk - Bukovinian Medical Bulletin, 20 (4(80), 246-249 [in Ukrainian].

7. Yuzbasheva, H.S. (2011). Dystantsiine navchannia u pisliadyplomnii osviti yak naukovyi suspilnyi priorytet [Distance learning in postgraduate education as a research public priority]. Pedahohichnyi almanakh - Pedagogical Almanac, 11, 220-226 [in Ukrainian].

8. Skrypnyk, L.M. (2012). Dystantsiina medychna osvita: suchasni realii ta problemy [Distance medical education: current issues and realities]. Arkhiv klinichnoi medytsynyThe Archive of Clinical Medicine, 2 (18), 116-118 [in Ukrainian].

Електронна адреса для листування: kozlova-irena@rambler.ru 